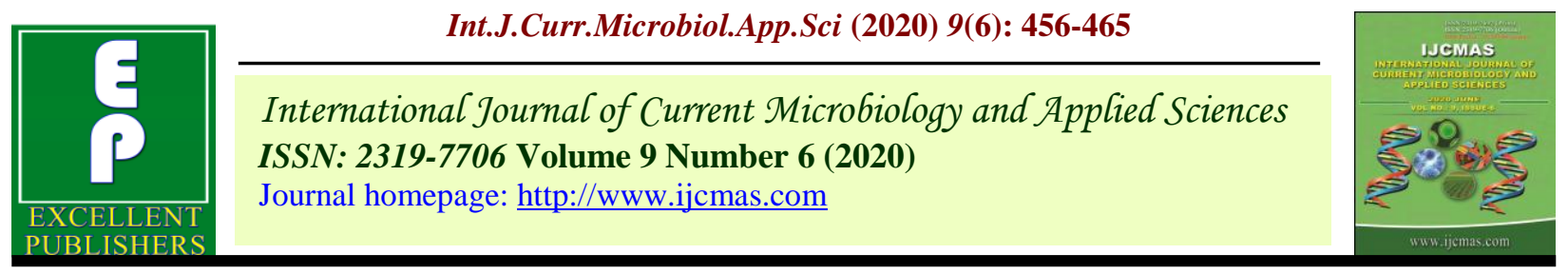

Original Research Article

https://doi.org/10.20546/ijcmas.2020.906.060

\title{
Effect of Sucker Weight on Growth and Yield of Banana (Musa spp.) cv. Barjahaji (AAA)
}

\author{
Himadri Shekhar Datta ${ }^{*}$, Kartik Baruah ${ }^{2}$, Sarat Sekhar Bora $^{3}$ and Karishma Borah ${ }^{4}$ \\ ${ }^{1}$ College of Horticulture, ${ }^{2}$ Department of Horticulture, \\ ${ }^{3}$ SMS (Agro-meteorology), KVK, Udalguri, ${ }^{4}$ Department of Horticulture, \\ Assam Agricultural University, Jorhat-785013, Assam, India \\ *Corresponding author
}

\section{A B S T R A C T}

\begin{tabular}{l} 
Ke y w o r d s \\
$\begin{array}{l}\text { Sucker, Growth, } \\
\text { Yield, pseudostem, } \\
\text { Harvest index }\end{array}$ \\
Article Info \\
$\begin{array}{l}\text { Accepted: } \\
\text { 15 May 2020 } \\
\text { Available Online: } \\
\text { 10 June } 2020\end{array}$ \\
\hline
\end{tabular}

A field experiment was undertaken at the Experimental Farm, Department of Horticulture, Assam Agricultural University, Jorhat during 2003-2004. The experiment was set in Randomized Block Design (RBD) consisting of three replications and eight treatments. The treatments comprised of $\mathrm{T}_{1}: \leq 500 \mathrm{~g}, \mathrm{~T}_{2}:>500-1000 \mathrm{~g}, \mathrm{~T}_{3}:>1000-1500 \mathrm{~g}, \mathrm{~T}_{4}:>1500$ $2000 \mathrm{~g}, \mathrm{~T}_{5}:>2000-2500 \mathrm{~g}, \mathrm{~T}_{6}:>2500-3000 \mathrm{~g}, \mathrm{~T}_{7}:>3000-3500 \mathrm{~g}$ and $\mathrm{T}_{8}:>3500-4000 \mathrm{~g}$. The results revealed that the growth parameters and yield attributes were significantly influenced by the treatments. Among them, $\mathrm{T}_{4}$ showed superiority in case of pseudostem height $(278.68 \mathrm{~cm})$, least phyllochron (7.76), and also shortened the planting shooting interval (181.05 days), shooting-harvest interval (97.15 days) and crop duration (278.27 days). However, $\mathrm{T}_{5}$ was observed to be the most effective for enhancement of maximum pseudostem girth $(68.30 \mathrm{~cm})$, total leaf production $(22.99)$, number of functional leaves (6.97) and leaf area index (3.17).Regarding the yield and yield attributing characters, the superiority of $\mathrm{T}_{4}$ could be noticed in respect of number of hands per bunch (8.01), length of finger $(24.06 \mathrm{~cm})$, girth of finger $(11.97 \mathrm{~cm})$, volume of finger $(209.36 \mathrm{cc})$, weight of finger $(149.97 \mathrm{~g})$ and harvest index (0.38). However, the treatment $\mathrm{T}_{5}$ exhibited the highest yield (62.71 t/ha), bunch weight $(20.36 \mathrm{~kg})$, number of fingers per hand $(15.70)$.

\section{Introduction}

Banana is a wonder berry constituting a major staple food of millions. In India it had been grown since time immemorial. It seems that it is one of the earliest fruit crops associated with mankind since the dawn of civilization. In India, banana has long period of domestication as evidenced by its mention in Kautilya's "Arthasastra" (250-300 B.C.) and its presence in the paintings and sculptures of Ajanta and Ellora (300-400 B.C.) Banana belongs to the section Eumusa under family Musaceae and botanically it is a monocotyledonous herbaceous plant (Purseglove, 1976).

Musaceae are strictly old world plants and predominantly Asian origin. The AssamMyanmar-Thailand area is supposed to be not 
only the centre of origin of banana but also their main centre of diversity. Banana is a tropical crop but grows well under subtropical condition as well.

India is now the largest producer of banana in the world producing 15.07 million tonnes from an area of 0.49 million hectares (Chadha, 2001). Assam ranks fourth occupying an area of 43.3 thousand hectares and an annual production of 600.8 thousand tonnes (Bhattacharyya, 2001).

Hence from the point of export, it is essential to give a serious thought at the position and status of production of this major commercial fruit of India for follow up action at national level to boost its export trade (Anon, 1989).

Banana has wide range of adaptability as evidenced by its presence from sea level to a height of 5000 feet and from the tropical to subtropical conditions with an array of varieties. A large number of banana cultivars are grown in Assam among which 'Jahaji', 'Barjahaji', 'Malbhog', 'Chenichampa' are mostly grown commercially.

\section{Materials and Methods}

The experiment was undertaken in the Experimental Farm of Department of Horticulture, Assam Agricultural University, Jorhat-785013, during the year 20032004.The experimental soil was sandy loam in texture, well drained and having $\mathrm{pH}$ 5.5.The experiment was set out in Randomized Block Design consisting of eight treatments replicated three times.

The area of the experimental plot was 915.84 sq.m. and that of the individual plot was 5.4 $\mathrm{m} \times 5.4 \mathrm{~m}\left(29.16 \mathrm{~m}^{2}\right)$. Suckers were planted at a spacing of $1.8 \mathrm{~m} \times 1.8 \mathrm{~m}$. The suckers of different weight range were considered as the treatments.
The treatments consisted of $\mathrm{T} 1 \quad(\leq 500), \mathrm{T} 2$ (>500-1000), T3 (>1000-1500), T4 (>15002000), T5 (>2000-2500), T6 (>2500-3000), $\mathrm{T} 7$ (>3000-3500) and $\mathrm{T}_{8} \quad(>3500-$ 4000)."Barjahaji”, a high yielding commercial variety of banana in Assam was identified as the material for this study. Fingers are long and green even at ripening. Flesh is soft and smooth. Healthy suckers of uniform age (about 3 month) and different weights were selected as the planting material. Before planting the top portion of the selected suckers were removed at $30 \mathrm{~cm}$ from the corm. The weighed suckers were pared and pralinaged by dipping them in a clay slurry with Carbofuran 3G @ 40 g per sucker.

The treated suckers were kept over night for suberization and planted in the field on April 8, 2003.Nitrogenous and Potassic fertilizers @ $240 \mathrm{~g}$ Urea $(46 \% \mathrm{~N})$ and $600 \mathrm{~g}$ Muriate of potash $\left(60 \% \mathrm{~K}_{2} \mathrm{O}\right)$ per plant respectively were applied in three splits in third, fifth and seventh month after planting. The whole amount of phosphatic fertilizer @ $210 \mathrm{~g}$ Single Super Phosphate $\left(16 \% \mathrm{P}_{2} \mathrm{O}_{5}\right)$ per plant was applied in third month after planting.

\section{Observations on growth characters}

Biometrical observations on the growth characters of the six tagged plants under each treatment were taken at 3 month, 5 month, shooting and harvest stages.

\section{Pseudostem height}

The pseudostem of the tagged plants were marked with black paint at $15 \mathrm{~cm}$ above the ground level. The height of the pseudostem was measured from the black mark to the point of intersection of the youngest first and second leaf axis. Finally the $15 \mathrm{~cm}$ length was added and the height was expressed in centimeter $(\mathrm{cm})$. 


\section{Pseudostem girth}

Girth of pseudostem was measured at 3 month, 5 month, shooting and harvest stages at $15 \mathrm{~cm}$ above the ground level and expressed in centimeter $(\mathrm{cm})$.

\section{Phyllochron}

The time interval between the production of two successive leaves was recorded in days and the mean value for each plant was determined.

\section{Total leaf number}

Total number of leaves produced by the plants during the entire growth period were counted from the first leaf emergence to the date of shooting.

\section{Functional leaves}

The number of functional leaves at 3 month, 5 month, shooting and harvest stages was recorded by counting only the green and healthy leaves. The leaves in which three fourth or whole of the total leaf area of the leaves were photosynthetically active, were considered as functional leaves. When more than three fourth of the total leaf area of the leaves became yellowish they were considered as senescent leaves which were discarded.

\section{Leaf area index (LAI)}

Leaf area index at 3 month, 5 month, shooting stage and harvesting stages were calculated by adopting the methods of Williams (1946).

$$
\text { LAI }=\frac{\text { Leaf area of three plants }}{\text { Area of land occupied by the three plants }}
$$

Leaf area calculations of the third leaf from the apex was done by multiplying the product of the length and breadth of the lamina with the factor 0.8 (Murray, 1960) and expressed in metre square $\left(\mathrm{m}^{2}\right)$. The length of the leaf was measured from the lamina base to its apex along the midrib as and when fully emerged and width was measured at the broadest portion of the lamina. The leaf area at small (3 months after planting), large (5 months after planting), shooting and harvest stages were determined.

To compute the total leaf area of the plant the leaf area of the third leaf was multiplied by the number of functional leaves recorded at that time (Murray, 1960).

\section{Days to shooting and harvesting}

The time period from planting to shooting and harvesting was recorded. It was calculated in days from the date of planting to emergence of inflorescence and till harvesting.

\section{Planting-shooting interval}

The date of shooting was noted on the day of emergence of first whorl of bloom and the days taken for shooting were counted from the date of planting.

\section{Shooting-harvest interval}

The duration from the date of shooting to the date of harvest was counted in days.

\section{Crop duration}

The crop duration was determined for each plant by counting the days from the date of planting to the date of harvest.

\section{Sucker production}

Total number of suckers produced per plant was recorded till shooting. 


\section{Observations on the yield characters}

\section{Bunch weight and yield}

At harvesting the bunch was cut leaving 22.5 $\mathrm{cm}$ above the first hand and $5 \mathrm{~cm}$ below the last hand. The bunches were weighed and expressed in kilogram $(\mathrm{kg})$. Yield in tonnes per hectare was calculated by multiplying the average bunch weight by the number of plants present in one hectare.

\section{Number of hands per bunch}

Total number of hands was counted for each bunch.

\section{Number of fingers per hand}

The total number of fingers was counted from the second hand.

\section{Length of finger}

Finger length was measured using a thread from the base of the pedicel to the tip of the fruit along with the dorsal curve at maturity and expressed in centimeter $(\mathrm{cm})$.

\section{Girth of finger}

Finger girth was measured at the middle portion of the fruit and expressed in centimeter $(\mathrm{cm})$.

\section{Volume of finger}

Finger volume was determined by using the following formula given by Simmonds (1953).

Where,

$$
\mathrm{V}=0.3537+0.0616 \mathrm{LC}^{2}
$$

$\mathrm{V}=$ Volume of the fruit in cc.

$\mathrm{L}=$ Length of the fruit in $\mathrm{cm}$.

$\mathrm{C}=$ Circumference or girth of the fruit at central portion in $\mathrm{cm}$. This gives a reasonably accurate measure of volume.

\section{Weight of finger}

Weight of individual finger from second hand at harvest was recorded and expressed in gram $(\mathrm{g})$.

\section{Harvest index}

Harvest index (on fresh weight basis) was calculated as per method suggested by Donald (1962).

Harvest index $=\frac{\text { Economic } \text { yield } \text { (bunch we } \text { ight in } \mathrm{kg} \text { ) }}{\text { Total biomass production in } \mathrm{kg}}$

\section{Results and Discussion}

\section{Effect on plant growth characters}

The use of suitable sucker weight significantly induced the vegetative growth at a faster rate in respect of height and girth of pseudostem under $\mathrm{T}_{4}$ and $\mathrm{T}_{5}$ treatment respectively as compared to rest of the treatments (Table: 1). This increase in plant height and girth may be due to unhindered growth of planting material and availability of large quantity of food material from large suckers prior to the development of wellestablished root system as explained by Samuels (1977) and Patel and Chundawat (1988).

The increase in girth has occurred probably as a result of natural loosening of compactness of the older leaf sheaths or may be due to pressure exerted around by the growing aerial stem pushing upward for shooting. Plant height has also contributed to the relative increase in plant girth in banana and this was substantiated by Chattopadhayay et al., (1980) who observed increased plant girth 
with the increase of plant height in 'Giant Governor' banana. Due to presence of more stored food materials, there was sufficient translocation of nutrients to the developing lateral buds to support a healthy growth of the plants. These findings are in conformity with the works of Balakrishnan (1980) and Berill (1960). Phyllochron was found to be favourably influenced by the treatments.

Treatment $\mathrm{T}_{4}$ recorded the shortest phyllochron (Table: 3). The variation in phyllochron of a cultivar of the same genomic constitution could be ascribed to several attributes such as low temperature (Summerville, 1944; Turner et al., 1986), nutritional status (Murray, 1960) and age (Champion, 1961).

The highest total leaf production under treatment $\mathrm{T}_{5}$ may be attributed to a better vegetative growth of its sucker in the early stages of growth with the aid of ample food materials stored in their parent materials. Number of functional leaves was found to be favourably influenced by $\mathrm{T}_{5}$ treatment. It was observed that with the increase size of planting materials there was increased retention of functional leaves by the suckers upto certain extent.

Higher retention of functional leaves with the suckers produced by the bigger size planting materials may be attributed to their higher rate of leaf production. Similarly, the lower rate of leaf production cause lower retention of functional leaves under smaller size planting materials as Stover (1977) clearly stated that the number of retention of functional leaves mainly determined by the age of the plant, number of leaves produced, climatic condition and nutrient status of soil. It has conformity with the findings of Sarkar and Barui (2004). The leaf area along with leaf area index was significantly increased in all the treatments upto the shooting stage and then showed a decreasing trend towards harvesting. Perusal of the data (Table 3) revealed that $T_{4}$ had significant effect on the total leaf area and leaf area index. The reason might be due to rapid production of leaves by the sucker which might increase the leaf area and leaf area index. Similar observations were also reported by Singh (1988).

As regards the planting-shooting interval and shooting-harvest interval, $\mathrm{T}_{4}$ followed by $\mathrm{T}_{5}$ recorded the least days in both the case while $\mathrm{T}_{8}$ and $\mathrm{T}_{3}$ showed the highest days respectively. Similarly the shortest crop duration was found in $T_{4}$ followed by $T_{5}$ while the highest was in $\mathrm{T}_{8}$. Several factors influence crop duration like time of planting (Biswas and Hussain, 1982).

Production of an optimum number of leaves and leaf area before the onset of flowering is an essential requisite for flowering and proper crop maturity in banana (Barker and Steward, 1962). The shortest crop duration might be due to higher net assimilation rate on account of better vegetative growth leading to the production of endogenous metabolites earlier in optimum level initiating early flower bud initiation and allowing early shooting. The leaf production could be related to bunch production in banana for the obvious reason that the rate of growth and the total biomass production depend very much on the numerical increase in the leaves.

This view was in the tune with that of Turner (1981) who had reported that leaf emergence rate would serve as a good index of the vegetative growth rate of a banana plant. The higher crop duration might also be due to more sucker production in those parent suckers. The food materials present in the parent material might be diverted and used by the daughter suckers which slowed down the growth process and increased the crop duration. 
Oppenheimer and Gottreich (1954) and Prasanna (1983) had suggested that the sucker size should be related to planting time in banana, since the size of sucker influenced the duration. Razvi and Jagirdar (1966) also reported earlier maturity with larger suckers.

The various sucker weight on sucker production showed significant results and highest number of suckers (8.74 and 7.64) were observed in $T_{8}$ and $T_{7}$ respectively. This may be attributed to the presence of comparatively higher number of buds enclosed by layer of leaf sheaths on it at the time of planting. Similar observation were also reported by Bora (1993). Balakrishnan (1980) also reported that the number of swollen buds on the corm had a positive association with the number of sucker produced. Nayar et al., (1978) also obtained maximum number of suckers per plant from the largest suckers of about $3.5 \mathrm{~kg}$ weight.

\section{Effect on yield and yield attributing characters}

Regarding the yield attributing characters like bunch weight, number of hands, finger numbers, finger weight, finger volume, length and girth of finger, all of them are the sum total effects of the growth as a whole of all the plant organs. Treatment $\mathrm{T}_{4}$ maintained the superiority over other treatments in number of hands per bunch, length of finger, girth of finger, volume of finger, weight of finger and harvest index. On the other hand, $\mathrm{T}_{5}$ was found superior to other treatments with a maximum bunch weight, yield and number of fingers per hand(Table: 5).

The leaf growth characteristics decide the duration of the crops and grade of the bunch in regard to their sizes and weights which finally result in production potentialities. Greater accumulation of dry matter conferred greater ability to give higher yields. Higher bunch weight might be due to the more number of leaves produced at all the growth stages (Azhakiamanavalan and MadhavaRao, 1980). Oppenheimer and Gottreich (1954) observed that the size of planting material would affect the yield only by affecting the flowering time. The significant increase in bunch weight was due to increased leaf area during the cropping period which accelerated the process of photosynthesis and carbohydrate formation. The relatively higher accumulation of carbohydrates in the leaves could promote growth rate and inturn increase the bunch yield (Gilbert, 1948). Leaf area have a positive correlation with the bunch weight. The correlation between bunch weight and leaf area was documented by Croucher and Mitchell (1940) and Murray (1961).

The increase in bunch weight was also found to be associated with corresponding increase in number of hands per bunch and number of fingers per hand. This might be due to better vegetative growth as compared to small size suckers as reported by Patel and Chundawat (1988). The results are in conformity with works of Nayar et al., (1978) and Sarkar and Barui (2004) who obtained highest bunch weight and hand and finger numbers per hand with the suckers of 1.5-2.0 kg weight.

Higher length, girth, volume and weight of fingers might also be due to better filling of fruits. More number of leaves might have increased the photosynthetic activity resulting in higher accumulation of carbohydrates in the leaf for translocation to the sink for better filling of fruits. The results are in conformity with the works of Pathak et al., (1992). Higher harvest index also gives an indication of economic yield. This might also be attributed to efficient partitioning of assimilates leading to the development of healthy bunch with higher grade and number of fingers. Similar trend was also reported by Bhattacharyya (1986) in banana. 
Table.1 Pseudostem height $(\mathrm{cm})$ and pseudostem girth $(\mathrm{cm})$ at different stages of growth

\begin{tabular}{|c|c|c|c|c|c|c|c|c|}
\hline Treatments & \multicolumn{4}{|c|}{ Pseudostem height (cm) } & \multicolumn{4}{c|}{ Pseudostem girth (cm) } \\
\cline { 2 - 10 } & $\mathbf{3}$ month & $\mathbf{5}$ month & $\begin{array}{c}\text { Shooting } \\
\text { stage }\end{array}$ & $\begin{array}{c}\text { Harvest } \\
\text { stage }\end{array}$ & $\mathbf{3}$ month & $\mathbf{5}$ month & $\begin{array}{c}\text { Shooting } \\
\text { stage }\end{array}$ & $\begin{array}{c}\text { Harvest } \\
\text { stage }\end{array}$ \\
\hline $\mathbf{T}_{\mathbf{1}}$ & 82.47 & 181.56 & 239.20 & 268.21 & 30.27 & 54.50 & 61.37 & $\mathbf{6 4 . 1 0}$ \\
\hline $\mathbf{T}_{\mathbf{2}}$ & 82.87 & 178.46 & 235.26 & 253.02 & 33.97 & 55.33 & 57.33 & $\mathbf{6 0 . 0 0}$ \\
\hline $\mathbf{T}_{\mathbf{3}}$ & 77.01 & 165.92 & 230.47 & 244.97 & 32.23 & 57.30 & 62.23 & $\mathbf{6 4 . 4 3}$ \\
\hline $\mathbf{T}_{\mathbf{4}}$ & 87.06 & 187.17 & 257.67 & 278.68 & 36.47 & 58.13 & 62.57 & $\mathbf{6 6 . 2 7}$ \\
\hline $\mathbf{T}_{\mathbf{5}}$ & 90.86 & 192.24 & 252.26 & 273.80 & 36.80 & 60.50 & 64.30 & $\mathbf{6 8 . 3 0}$ \\
\hline $\mathbf{T}_{\mathbf{6}}$ & 72.62 & 160.43 & 231.89 & 252.79 & 30.13 & 53.13 & 60.10 & $\mathbf{6 3 . 2 7}$ \\
\hline $\mathbf{T}_{\mathbf{7}}$ & 82.23 & 162.15 & 221.14 & 240.92 & 33.17 & 56.30 & 60.60 & $\mathbf{6 3 . 5 3}$ \\
\hline $\mathbf{T}_{\mathbf{8}}$ & 81.68 & 163.68 & 233.87 & 247.16 & 32.27 & 53.30 & 61.47 & $\mathbf{6 4 . 1 3}$ \\
\hline $\mathbf{S . E d}_{\mathbf{E}} \mathbf{\pm}$ & 0.27 & 0.36 & 0.44 & 0.23 & 0.17 & 1.61 & 0.26 & $\mathbf{0 . 2 5}$ \\
\hline $\mathbf{C D}_{\mathbf{0 . 0 5}}$ & $\mathbf{0 . 5 8}$ & $\mathbf{0 . 7 6}$ & $\mathbf{0 . 9 4}$ & $\mathbf{0 . 4 9}$ & $\mathbf{0 . 3 6}$ & $\mathbf{3 . 4 6}$ & $\mathbf{0 . 5 6}$ & $\mathbf{0 . 5 3}$ \\
\hline
\end{tabular}

Table.2 Total leaf production, number of functional leaves and phyllochron at different stages of growth

\begin{tabular}{|c|c|c|c|c|c|c|c|c|c|}
\hline \multirow[t]{2}{*}{ Treatments } & \multicolumn{3}{|c|}{$\begin{array}{l}\text { Total leaf production } \\
\text { (per plant) }\end{array}$} & \multicolumn{4}{|c|}{$\begin{array}{c}\text { Number of functional leaves } \\
\text { (per plant) }\end{array}$} & \multicolumn{2}{|c|}{$\begin{array}{l}\text { Phyllochron } \\
\text { (days) }\end{array}$} \\
\hline & $\begin{array}{c}3 \\
\text { month }\end{array}$ & $\begin{array}{c}5 \\
\text { month }\end{array}$ & $\begin{array}{l}\text { Shooting } \\
\text { stage }\end{array}$ & $\begin{array}{c}3 \\
\text { month }\end{array}$ & $\begin{array}{c}5 \\
\text { month }\end{array}$ & $\begin{array}{l}\text { Shooting } \\
\text { stage }\end{array}$ & $\begin{array}{l}\text { Harvest } \\
\text { stage }\end{array}$ & $\begin{array}{c}3 \\
\text { month }\end{array}$ & $\begin{array}{c}5 \\
\text { month }\end{array}$ \\
\hline $\mathbf{T}_{1}$ & 10.55 & 17.17 & 20.76 & 5.76 & 5.48 & 6.15 & 2.51 & 9.09 & 9.80 \\
\hline $\mathbf{T}_{2}$ & 11.67 & 18.12 & 22.06 & 5.82 & 6.04 & 6.26 & 3.71 & 8.09 & 9.01 \\
\hline $\mathbf{T}_{3}$ & 11.47 & 17.89 & 21.73 & 5.61 & 5.89 & 6.21 & 4.17 & 8.86 & 9.40 \\
\hline $\mathbf{T}_{4}$ & 12.07 & 19.15 & 22.45 & 5.95 & 6.13 & 6.58 & 4.75 & 7.76 & 8.87 \\
\hline$T_{5}$ & 12.38 & 19.38 & 22.99 & 6.10 & 6.59 & 6.97 & 4.85 & 7.82 & 8.96 \\
\hline$T_{6}$ & 10.96 & 17.68 & 20.87 & 5.25 & 5.93 & 6.29 & 3.96 & 9.08 & 9.46 \\
\hline $\mathbf{T}_{7}$ & 11.22 & 18.44 & 21.16 & 5.89 & 6.15 & 6.40 & 4.33 & 8.16 & 9.30 \\
\hline $\mathbf{T}_{8}$ & 11.44 & 18.65 & 21.69 & 5.67 & 6.10 & 6.34 & 3.05 & 8.01 & 9.59 \\
\hline S.Ed. \pm & 0.02 & 0.02 & 0.03 & 0.05 & 0.01 & 0.03 & 0.02 & 0.03 & 0.01 \\
\hline $\mathrm{CD}_{0.05}$ & 0.05 & 0.05 & 0.05 & 0.12 & 0.02 & 0.06 & 0.05 & 0.07 & 0.02 \\
\hline
\end{tabular}

Table.3 Total leaf area $\left(\mathrm{m}^{2}\right)$ and Leaf Area Index (LAI) at different stages of growth

\begin{tabular}{|c|c|c|c|c|c|c|c|c|}
\hline Treatments & \multicolumn{4}{|c|}{ Total leaf area $\mathbf{( m}^{\mathbf{2}}$ ) } & \multicolumn{3}{c|}{ Leaf area index (LAI) } \\
\cline { 2 - 10 } & $\begin{array}{c}\mathbf{3} \\
\text { month }\end{array}$ & $\begin{array}{c}\mathbf{5} \\
\text { month }\end{array}$ & $\begin{array}{c}\text { Shooting } \\
\text { stage }\end{array}$ & $\begin{array}{c}\text { Harvest } \\
\text { stage }\end{array}$ & $\begin{array}{c}\mathbf{3} \\
\text { month }\end{array}$ & $\begin{array}{c}\mathbf{5} \\
\text { month }\end{array}$ & $\begin{array}{c}\text { Shooting } \\
\text { stage }\end{array}$ & $\begin{array}{c}\text { Harvest } \\
\text { stage }\end{array}$ \\
\hline $\mathbf{T}_{\mathbf{1}}$ & 0.36 & 1.01 & 1.24 & 1.10 & 0.64 & 1.71 & 2.36 & $\mathbf{0 . 8 5}$ \\
\hline $\mathbf{T}_{\mathbf{2}}$ & 0.41 & 0.94 & 1.09 & 0.97 & 0.73 & 1.74 & 2.06 & $\mathbf{1 . 1 1}$ \\
\hline $\mathbf{T}_{\mathbf{3}}$ & 0.43 & 0.96 & 1.30 & 0.94 & 0.72 & 1.74 & 2.39 & $\mathbf{1 . 2 0}$ \\
\hline $\mathbf{T}_{\mathbf{4}}$ & 0.59 & 1.17 & 1.41 & 1.31 & 1.08 & 2.21 & 2.66 & $\mathbf{1 . 9 1}$ \\
\hline $\mathbf{T}_{\mathbf{5}}$ & 0.51 & 1.09 & 1.48 & 1.18 & 0.95 & 2.22 & 3.17 & $\mathbf{1 . 7 7}$ \\
\hline $\mathbf{T}_{\mathbf{6}}$ & 0.39 & 0.85 & 1.08 & 0.95 & 0.64 & 1.54 & 2.09 & $\mathbf{1 . 1 5}$ \\
\hline $\mathbf{T}_{\mathbf{7}}$ & 0.34 & 0.89 & 1.05 & 0.99 & 0.62 & 1.69 & 2.08 & $\mathbf{1 . 3 2}$ \\
\hline $\mathbf{T}_{\mathbf{8}}$ & 0.34 & 0.85 & 1.16 & 1.05 & 0.59 & 1.60 & 2.18 & $\mathbf{0 . 9 9}$ \\
\hline $\mathbf{S . E d}_{\mathbf{\pm}} \mathbf{E}$ & 0.01 & 0.01 & 0.01 & 0.01 & 0.02 & 0.02 & 0.03 & $\mathbf{0 . 0 2}$ \\
\hline $\mathbf{C D}_{\mathbf{0 . 0 5}}$ & $\mathbf{0 . 0 3}$ & $\mathbf{0 . 0 3}$ & $\mathbf{0 . 0 3}$ & $\mathbf{0 . 0 3}$ & $\mathbf{0 . 0 5}$ & $\mathbf{0 . 0 5}$ & $\mathbf{0 . 0 7}$ & $\mathbf{0 . 0 4}$ \\
\hline
\end{tabular}


Table.4 Planting-shooting interval, shooting-harvest interval, crop duration (values in days) and sucker production

\begin{tabular}{|c|c|c|c|c|c|c|}
\hline \multirow[t]{2}{*}{ Treatment } & \multirow{2}{*}{$\begin{array}{l}\text { Planting } \\
\text { shooting } \\
\text { interval }\end{array}$} & \multirow{2}{*}{$\begin{array}{c}\text { Shooting } \\
\text { harvest } \\
\text { interval }\end{array}$} & \multirow{2}{*}{$\begin{array}{c}\text { Crop } \\
\text { duration } \\
\text { (days) }\end{array}$} & \multicolumn{3}{|c|}{ Sucker production (number/plant) } \\
\hline & & & & 3 month & 5 month & $\begin{array}{c}\text { Shooting } \\
\text { stage }\end{array}$ \\
\hline $\mathbf{T}_{1}$ & 203.77 & 111.43 & 315.14 & 1.88 & 4.51 & 6.03 \\
\hline $\mathbf{T}_{2}$ & 210.67 & 108.66 & 318.79 & 2.25 & 5.32 & 6.62 \\
\hline $\mathbf{T}_{3}$ & 203.69 & 116.30 & 316.99 & 3.02 & 5.05 & 6.48 \\
\hline $\mathbf{T}_{4}$ & 181.05 & 97.15 & 278.27 & 3.42 & 5.63 & 7.31 \\
\hline $\mathbf{T}_{5}$ & 195.06 & 101.10 & 296.16 & 3.12 & 5.07 & 6.96 \\
\hline$T_{6}$ & 215.44 & 105.03 & 320.47 & 2.96 & 4.94 & 6.77 \\
\hline $\mathbf{T}_{7}$ & 229.38 & 105.44 & 334.82 & 3.67 & 6.00 & 7.64 \\
\hline $\mathbf{T}_{8}$ & 231.01 & 104.03 & 335.04 & 3.87 & 6.06 & 8.74 \\
\hline S.Ed. \pm & 1.91 & 0.78 & 1.13 & 0.03 & 0.02 & 0.02 \\
\hline $\mathrm{CD}_{0.05}$ & 4.09 & 1.67 & 2.43 & 0.06 & 0.05 & 0.05 \\
\hline
\end{tabular}

Table.5 Yield and yield attributing characters

\begin{tabular}{|c|c|c|c|c|c|c|c|c|c|}
\hline Treatments & $\begin{array}{c}\text { Bunch } \\
\text { weight } \\
\text { (kg) }\end{array}$ & $\begin{array}{c}\text { Number of } \\
\text { hands/bunch }\end{array}$ & $\begin{array}{c}\text { Number of } \\
\text { fingers/hand }\end{array}$ & $\begin{array}{c}\text { Length } \\
\text { of } \\
\text { finger }\end{array}$ & $\begin{array}{c}\text { Girth } \\
\text { of } \\
\text { finger }\end{array}$ & $\begin{array}{c}\text { Volume } \\
\text { of } \\
\text { finger } \\
\text { (cm) }\end{array}$ & $\begin{array}{c}\text { Weight } \\
\text { of })\end{array}$ & $\begin{array}{c}\text { Harvest } \\
\text { index } \\
\text { finger } \\
\text { (g) }\end{array}$ & $\begin{array}{c}\text { Yield } \\
\text { (t/ha) }\end{array}$ \\
\hline $\mathbf{T}_{\mathbf{1}}$ & 17.03 & 7.42 & 13.70 & 22.50 & 11.31 & 181.74 & 130.78 & 0.32 & $\mathbf{5 2 . 4 9}$ \\
\hline $\mathbf{T}_{\mathbf{2}}$ & 12.71 & 7.25 & 13.43 & 23.05 & 11.57 & 191.04 & 147.00 & 0.29 & $\mathbf{3 9 . 1 0}$ \\
\hline $\mathbf{T}_{\mathbf{3}}$ & 12.20 & 7.73 & 12.70 & 20.99 & 10.08 & 129.63 & 114.11 & 0.26 & $\mathbf{3 7 . 5 9}$ \\
\hline $\mathbf{T}_{\mathbf{4}}$ & 19.69 & 8.00 & 14.65 & 24.06 & 11.97 & 209.36 & 149.97 & 0.38 & $\mathbf{6 0 . 7 1}$ \\
\hline $\mathbf{T}_{\mathbf{5}}$ & 20.36 & 7.93 & 15.70 & 23.40 & 11.67 & 204.93 & 148.29 & 0.35 & $\mathbf{6 2 . 7 1}$ \\
\hline $\mathbf{T}_{\mathbf{6}}$ & 16.04 & 7.08 & 13.65 & 22.04 & 11.10 & 171.49 & 121.83 & 0.30 & $\mathbf{4 9 . 4 1}$ \\
\hline $\mathbf{T}_{\mathbf{7}}$ & 14.36 & 7.66 & 14.33 & 22.20 & 11.18 & 173.53 & 117.15 & 0.32 & $\mathbf{4 4 . 2 7}$ \\
\hline $\mathbf{T}_{\mathbf{8}}$ & 17.66 & 7.30 & 13.39 & 22.36 & 11.16 & 202.77 & 136.74 & 0.33 & $\mathbf{5 4 . 5 8}$ \\
\hline $\mathbf{S . E d}_{\mathbf{m}} \boldsymbol{\pm}$ & 0.02 & 0.03 & 0.02 & 0.04 & 0.02 & 0.41 & 0.33 & 0.005 & $\mathbf{0 . 0 2}$ \\
\hline $\mathbf{C D}_{\mathbf{0 . 0 5}}$ & $\mathbf{0 . 0 4}$ & $\mathbf{0 . 0 7}$ & $\mathbf{0 . 0 4}$ & $\mathbf{0 . 0 8}$ & $\mathbf{0 . 0 5}$ & $\mathbf{0 . 8 8}$ & $\mathbf{0 . 7 1}$ & $\mathbf{0 . 0 1}$ & $\mathbf{0 . 0 4}$ \\
\hline & & & & & & & & & \\
\hline
\end{tabular}

From the experiment it could be concluded that use of suckers weighing 1500-2500g would be profitable for good vegetative growth and yield of Barjahaji banana under the agro-climatic condition of Jorhat.

\section{References}

Anon. (1989). Agricultural situation in India. April, 1989. Ministry of Agriculture, Govt. of India.

Azhakiamanavalan, R.S. and Madhava, Rao, U.N. (1980). A Comparative study of 'Hybrid-135' and 'Virupakshi' banana. Proc. Natl. Sem. On Banana Prod.
Tech. TNAU, Coimbatore, pp. 62-64.

Balakrishnan, R. (1980). Studies on growth, development, sucker production and nutrient uptake at different ploidy level in banana. Ph.D Thesis, TNAU, Coimbatore.

Barker, W.G. and Steward, F.C. (1962). Growth and development of banana plant. 1. The growing regions of the vegetative shoot. Ann. Bot., (London). N.S., 26: 189-411.

Berrill, F.W. (1960). Plant growth and yield in the Cavendish banana (Musa cavendishi Lamb) as affected by size and type of planting material. $Q d$. $J$. 
agric. Sci. 17: 69-81.

Bhattacharyya, R.K. (1986). Harvest Index, dry matter production and shoot-root ratio of 'Robusta' banana as influenced by soil covers and soil moisture regimes. Paper presented at XXII International Horticultural Congress, ISHS, California, Aug. 11-20, 1986.

Bhattacharyya, R.K. (2001). Horticultural Crops-Fruit and Vegetables. In: Agriculture in Assam (AAU, Jorhat-13).

Biswas, M. and Hossain, A.K.M.A. (1982). Studies on the influence of planting time on the performance of five exotic plantation cultivars. Bangladesh Hort.10: 31-33.

Bora, K. (1993). Standardization of planting materials on sucker production of Banana cv. 'Barjahaji'. M.Sc. (Agri.) Thesis, AAU, Jorhat.

Chadha, K.L. (2001). Food nutrition and environmental security through horticultural crops. Ind. J. Hort. 45(4): 2.

Champion, J. (1961). Preliminary indications on the growth of Poyo banana. Fruits. 16: 191-94.

Chattopadhyay, P.K.; Maiti, S.C.; Sen, S.K. and Bose, T.K. (1980). Effect of time of planting and type of planting material on growth, yield and quality of banana. Proc. Natl. Sem. On Banana Prod. Tech. TNAU, Coimbatore, pp. 85-88.

Croucher, H.H. and Mitchell, W.K. (1940). Fertilizer investigation with the Gros Michel banana. Bull. Dept. Sci. Agr. Jamaica. No. 19: 1-30. Temperate to Tropical Fruit Nutrition. Ed. Norman F. Childers. Chapt. III. Hort. Publs. USA, pp. 77-100, 1966.

Donald, C.M. (1962). In search of yield. Aust. Inst. Agric. Sci. 28: 171-78.

Gilbert, F.A. (1948). Mineral nutrition of plants and animals. Univ. Oklahoma Press, Oklahoma.

Murray, D.B. (1960). The effect of deficiencies of major nutrients on growth and leaf analysis of the banana. Trop. Agric. Trin. 37: 97-106.

Murray, D.B. (1961). Shade fertilizer relations in banana Trop. Agric. Trin. 38: 123-131.

Nayar, N.K.; Balakrishnan, S. and Shilaja, S. (1978). Effect of weight of suckers of Nendran banana on plant growth and yield. Agric Res. J. Kerala. 16(2): 25759.

Oppenheimer, C. and Gottreich, M.C. (1954). Studies on growth and development of the dwarf banana in the coastal plain of Israel. Ktavim.5: 29-55.

Patel, N.L. and Chundawat, B.S. (1988). Effect of size and resting period of suckers on growth and yield of banana. Ind. J. Hort. 45(3-4): 189-96.

Patel, N.L. and Chundawat, B.S. (1988). Effect of size and resting period of suckers on growth and yield of banana. Ind. J. Hort. 45(3-4): 189-96.

Pathak, R.A.; Singh, B.V. and Ojha, C.M. (1992). Studies on the growth and yield of banana cv. 'Harichal'. Ntl. Symp. on Optimization and Productivity and Utilization of Banana. Sept., 22-23, 1992, pp. 38.

Prasanna, K.P. (1983). Performance of clonal progenies from different yield groups and in relation to size of suckers in rainfed banana (AAB) cv. Palayankodan M.Sc. (Hort). Thesis, KAU. Vellanikkara.

Razvi, I.A. and Jagirdar, S.A.P. (1966). Effect of sucker size at planting time and subsequent population on the growth and production of banana. W. Pakist. J. Agric. Res. 4(3): 84-100.

Samuels, G. (1977). The influence of corm size on initial plantain growth. J. Agric. Univ. of Puerto Rico. 61(3): 386-88.

Sarkar, S.K. and Barui, F.K. (2002). Res. Report. AICRP and ICAR Ad-hoc Res. Schemes on Tropical Fruits. TNAU, 
Coimbatore.

Sarkar, S.K. and Barui, F.K. (2004). Res. Report. AICRP and ICAR Ad-hoc. Res. Schemes on Tropical Fruits. TNAU, Coimbatore.

Simmonds, N.W. (1953). The development of banana fruits. J. Exp. Bot. 4: 37-40.

Singh, R.K.D. (1988). Studies on growth and development of some banana cultivars. M.Sc. (Agri). Thesis, AAU. Jorhat.

Stover, R.H. (1977). Pseudostem growth, leaf production and flower initiation in the 'Grand Nain' banana. Bull Trop. Agric. Services. 8: 37
Summerville, W.A.T. (1944) Studies on nutrition as qualified by development in Musa cavendishii L. Qd. J. Agric. Sci1: 1-127.

Turner, D.W and Hunt, N. (1986). The relationship between temperature and rate of appearance of new leaves on thirty banana varieties grown in Sub tropics. Garica De Orta. Extudis Agronomics. 10: 91-94.

Turner, D.W. (1981). Crop Physiology of banana - quo vadis ?Madras Agril. J. 68: 73-84.

\section{How to cite this article:}

Himadri Shekhar Datta, Kartik Baruah, Sarat Sekhar Bora and Karishma Borah. 2020. Effect of Sucker Weight on Growth and Yield of Banana (Musa spp.) cv. Barjahaji (AAA). Int.J.Curr.Microbiol.App.Sci. 9(06): 456-465. doi: https://doi.org/10.20546/ijcmas.2020.906.060 